\title{
INVESTIGATION OF SUSCEPTIBILITY AND RESISTANCE MECHANISMS OF SOME EGYPTIAN WHEAT CULTIVARS (Triticum aestivum L.) INOCULATED WITH Blumeria graminis f.sp. tritici USING CERTAIN BIOCHEMICAL, MOLECULAR CHARACTERIZATION AND SEM \\ Hafez , Y. M. ${ }^{1}$ and Kh. A.A. Abdelaal ${ }^{2}$ \\ ${ }^{1}$ Plant Pathology Branch, Agricultural Botany Dept., ${ }^{2}$ Agricultural Botany Branch, Agricultural Botany Dept., Faculty of Agriculture, Kafrelsheikh University, Egypt hafezyasser@gmail.com
}

\begin{abstract}
Two greenhouse experiments were conducted in the greenhouse of Agricultural Botany Department, Faculty of Agriculture, Kafrelsheikh University, Egypt, during two seasons (2012-2013 and 2013-2014) to study biochemical, molecular characterization and SEM investigation of susceptibility and resistance mechanisms of ten Egyptian wheat cultivars (Sakha 93, Sakha 94, Sids 12, Sids 13, Giza 160, Giza 168, Giza 171, Misr 1, Misr 2 and Gemmiza 11) inoculated with Blumeria graminis $\mathrm{f}$. $\mathrm{sp}$. tritici fungus the causal organism of wheat powdery mildew. This disease one of most important diseases of wheat worldwide. Chemical and biological control methods are used routinely to control the disease. However, resistant cultivars are still the best control strategy. Consequently, characterization of susceptibility and resistance mechanisms is very important and required essentially. In wheat susceptible cultivars (Sakha 93, Sakha 94, Sids 12 and Sids 13), moderately susceptible (Giza 160), moderately resistant (Giza 168, Giza 171, Misr 1), resistant (Misr 2) and highly resistant cultivars Gemmiza 11) when inoculated with powdery mildew fungus, the percent of disease severity were significantly decreased in resistant cultivars compared with susceptible ones. Indeed the disease symptoms and electrolyte leakage were also significantly decreased in resistant cultivars. As well as levels of reactive oxygen species (ROS), such as superoxide $\left(\mathrm{O}_{2}{ }^{-}\right)$and hydrogen peroxide $\left(\mathrm{H}_{2} \mathrm{O}_{2}\right)$ significantly accumulated early 6 and 12 hours after inoculation (hai) in the resistant cultivars. Consequently, catalase (CAT), superoxide dismutase (SOD) and peroxidase (POX) enzyme activities were significantly stimulated at 24-72 hai. Significant increase of chlorophyll $a$ and b concentrations was found. However, in the susceptible inoculated cultivars, the fungus was intensively colonized with huge quantity of conidia spores compared with the moderately resistant, resistant and highly resistant cultivars using scanning electron microscope (SEM). Molecular investigations using PCR (SSR) technique proved that the resistant gene Pm38 over expressed and accumulated in resistant cultivars not in susceptible ones. Expression of Pm38 gene was correlated with the resistance degrees. It can be recommended giving more attention to these new mechanisms of resistance to improve and find out new resistant cultivars which over expressed new resistant-mediated-ROS genes.
\end{abstract}

Keywords: Triticum aestivum L., Blumeria graminis f.sp. tritici, Scanning Electron Microscope (SEM), Antioxidants, Resistant Pm38 gene, ROS

\section{INTORODUCTION}

It is well known that wheat (Triticum aestivum L.) crop is one of the most vital cereal crops all over the world (Peng et al., 2000; Wang et al., 2002; Chen et al., 2003; Abdelaal et al., 2014). 
Powdery mildew disease caused by the fungus Blumeria graminis $\mathrm{f} . \mathrm{sp}$. tritici (Bgt) which is a common pathogenic disease distributed in various wheat production countries, causing significant loss of yield (Leath et al., 1989; Griffey, 1993). Fungicide treatment is regularly carried out to control cereal diseases. However, the development of fungicide resistant strains limited the fungicides usage. In addition, fungicides act as a hazard effects on human health and environmental pollution (Wilson et al., 1994; Hafez et al., 2014a; Abdelaal et al., 2014). Resistant cultivars are the most real and economical method in controlling plant diseases (Röbbelen and Sharp, 1978; Line and Chen, 1995).

Using traditional breeding, certain resistant genes to powdery mildew pathogen in wild relatives of wheat have been transferred to the susceptible common wheat generating a series of isogeniclines showing varying degrees of resistance to a number of powdery mildew types. These powdery mildewresistant lines have been suggested as the most economical and environmentally safe cultivars for disease control. It could be used as natural materials in the laboratory for a better characterization of the molecular mechanisms of the host-pathogen interaction and defense response in plants (Bhullar et al., 2009; Brunner et al., 2011). Advanced studies were conducted to clarify structural components and molecular mechanisms of resistance response in wheat (Wang et al., 2010; Hafez et al., 2014b; Abdelaal et al., 2014). Resistant host plant is the greatest real means to control the powdery mildew disease, then, planting resistant cultivars are recommended. However, different races of the fungus can occur from one year to the next and might overcome resistance. Different methods have been done to classify the pathogen-resistant genes in wheat which responding to several types of crop diseases (Bernardo et al., 2007; Coram et al., 2008). It was shown that 44 genes are differentially expressed at 72 hours after inoculation (hai) against Fusarium spp., and cause head blight resistant and/or susceptible (Bernardo et al., 2007).

Infections of plants with phytopathogens (mostly fungi, bacteria and viruses) in many cases are accompanying with the accumulation of ROS which induces oxidative stress in plants (Hafez et al., 2012). Under natural conditions, up-regulation of antioxidant defense systems seems to be a general response to oxidative stress (Halliwell and Gutteridge, 1999; Hafez and El-Baghdady 2013). Hydrogen peroxide $\left(\mathrm{H}_{2} \mathrm{O}_{2}\right)$ and superoxide $\left(\mathrm{O}_{2}{ }^{-}\right)$are the most important ROS associated with oxidative stress, which up-regulate antioxidant systems even at very low concentrations (Gechev et al., 2002; Hafez et al., 2012). ROS are produced by all aerobic organisms as byproducts of several metabolic pathways, including electron flows in mitochondria and chloroplasts, lipid catabolism and photorespiration in glyoxysomes and peroxisomes as well as enzymatic oxygenase reactions having a different cellular localization. In order to avoid ROS toxicity, aerobic cells are provided with a flexible set of enzymes and metabolites involved in ROS catabolism, which often acts at the site of ROS production. Although much metabolic energy is spent on ROS removal by plant cells, ROS are also actively produced by cell metabolism under optimal growth conditions (Heath, 2000). When ROS over accumulated early after the infection either in 
resistant wheat cultivars against wheat stripe rust (Abdelaal et al., 2014) or ROS stimulated in susceptible barley cultivars treated with resistant inducers (Hafez et al., 2014b) the fungus inhibited or killed early after infection. Fortunately, cells make a variety of antioxidant enzymes to fight the dangerous side-effects of life with oxygen. Two important players are superoxide dismutase, which converts $\mathrm{O}_{2}^{-{ }^{-}}$into $\mathrm{H}_{2} \mathrm{O}_{2}$, and catalase, which converts $\mathrm{H}_{2} \mathrm{O}_{2}$ into water and oxygen gas (Apel and Hirt, 2004).

The present investigation aimed to clarify the biochemical, histochemical and molecular mechanisms associated with susceptibility and resistance of wheat cultivars inoculated with Blumeria graminis $\mathrm{f}$. $\mathrm{sp}$. tritici the powdery mildew fungus. The activities of antioxidant enzymes, ROS levels, disease severity, electrolyte leakage, chlorophyll $a / b$ concentrations, scanning electron microscope (SEM) examination and accumulation of resistance gene Pm38 were determined.

\section{MATERIALS AND METHODS}

\section{Plant materials}

The research experiments were conducted in the greenhouse of Agricultural Botany Department, Faculty of Agriculture, Kafrelsheikh University, Egypt, during two growing seasons (2012-2013 and 2013-2014). Ten Egyptian wheat cultivars (Sakha 93, Sakha 94, Sids 12, Sids 13, Giza 160, Giza 168, Giza 171, Misr 1, Misr 2 and Gemmiza 11) were used. Ten grains of each cultivar were sown/plastic pot $(7 \mathrm{~cm}$ diam.) in a formalin sterilized soil mixture $(5: 2: 1 \mathrm{v} / \mathrm{v} / \mathrm{v})$ of clay, sand and peat moss. Pots were placed in spore-proof greenhouse cabins under 16 hours light $\left(17^{\circ} \mathrm{C}\right)$ and 8 hours darkness $\left(12^{\circ} \mathrm{C}\right)$. An artificial light of $50-100 \mu \mathrm{Em}^{-2} \mathrm{~s}^{-1}$ was applied when daylight was less than 10000 lux. Wheat seedlings were inoculated at 7-8 days (Awad et al., 2015).

\section{Artificial inoculation}

Tables 1 and 2 show that artificial inoculation was carried out using rubbing technique at the flag leaf according to the method of Large (1954). Spores were harvested from infected seedlings of the susceptible cultivar (Sakha 93). Infected samples were kept in living susceptible wheat cultivar to be used in further studies and kept in per gamin envelops in fridge at 5-10 $\mathrm{C}^{\circ}$. Each sample was picked and inoculated on 7-8 days seedlings of wheat cultivars (Awad et al., 2015). Three replicates were inoculated for each cultivar. Then inoculated seedlings were placed under trays, sprayed with water and covered to keep $100 \%$ fresh during incubation at $10^{\circ} \mathrm{C}$ for 22 hours. After that pots were transferred to the greenhouse and randomized in a spore-proof cabin (Chris, 2012).

Disease severity:

Infection types were scored 2 and 12 weeks after inoculation in seedling stage and at adult stage, respectively according to the methods of Shi et al., (1987) and Leath and Heun, (1990), respectively, as shown in Tables (1 and 2). 
Table (1): Infection types of inoculated wheat at seedling stage

\begin{tabular}{|c|c|c|c|}
\hline Host & Response (class) & $\begin{array}{l}\text { Infection } \\
\text { types }\end{array}$ & Disease symptoms \\
\hline \multirow{4}{*}{ 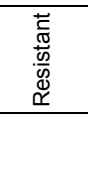 } & Immune & Low 0 & No visible symptoms \\
\hline & Nearly immune & Low 0 & Hypersensitive necrotic flecks \\
\hline & Very resistant & Low 1 & Minute colonies with few conidia produced \\
\hline & $\begin{array}{l}\text { Moderately } \\
\text { resistant }\end{array}$ & Low 2 & $\begin{array}{c}\text { Colonies with moderately developed } \\
\text { hyphae, but few conidia }\end{array}$ \\
\hline \multirow{2}{*}{ 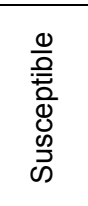 } & $\begin{array}{l}\text { Moderately } \\
\text { susceptible }\end{array}$ & High 3 & $\begin{array}{c}\text { Colonies with well-developed hyphae } \\
\text { and abundant conidia, but colonies } \\
\text { not joined together few conidia }\end{array}$ \\
\hline & Very susceptible & High 4 & $\begin{array}{c}\text { Colonies with well-developed hyphae } \\
\text { and abundant conidia, and colonies } \\
\text { mostly joined together }\end{array}$ \\
\hline
\end{tabular}

Table (2): Infection types of inoculated wheat at adult stage

\begin{tabular}{|c|c|c|}
\hline $\begin{array}{l}\text { Infection } \\
\text { type }\end{array}$ & Host response & Symptoms \\
\hline 0 & Immune & No visible sings or symptoms \\
\hline 1 & Highly resistant & Small flecks only \\
\hline 2 & Resistant & Chlorosis flecks evident \\
\hline 3 & Moderately resistant & Large flecks with chlorosis and necrosis \\
\hline 4 & Intermediate & Mycelium and conidia detectable \\
\hline 5 & $\begin{array}{l}\text { Moderately } \\
\text { susceptible }\end{array}$ & $\begin{array}{l}\text { Small to moderate sized pustules and conidia } \\
\text { present }\end{array}$ \\
\hline 6 & $\begin{array}{l}\text { Moderately } \\
\text { susceptible }\end{array}$ & $\begin{array}{c}\text { Predominance of moderate sized pustules and } \\
\text { conidia present }\end{array}$ \\
\hline 7 & Susceptible & $\begin{array}{c}\text { At the least } 50 \% \text { of the large pustules and } \\
\text { conidia are visual }\end{array}$ \\
\hline 8 & Susceptible & $\begin{array}{c}75 \text { to } 80 \% \text { of the leaf segment were covered } \\
\text { with large pustules and conidia }\end{array}$ \\
\hline 9 & Highly susceptible & $\begin{array}{l}100 \% \text { of the leaf segment curved with large } \\
\text { pustules and conidia }\end{array}$ \\
\hline
\end{tabular}

\section{Histochemical detection of $\mathrm{O}_{2}{ }^{--}$and $\mathrm{H}_{2} \mathrm{O}_{2}$}

Detection of $\mathrm{O}_{2}$ and $\mathrm{H}_{2} \mathrm{O}_{2}$ were visualized as a purple coloration of nitro blue tetrazolium (NBT) and a reddish-brown coloration of 3,3-diaminobenzidine (DAB), respectively. Wheat leaves were vacuum infiltrated with $10 \mathrm{mM}$ potassium salicylate buffer $(\mathrm{pH} 7.8)$ containing $0.1 \mathrm{w} / \mathrm{v} \%$ NBT (Sigma-Aldrich, Steinheim, Germany) or $0.1 \mathrm{w} / \mathrm{v} \%$ DAB (Fluka, Buchs, Switzerland). NBT- and DAB-treated samples were incubated under daylight for $20 \mathrm{~min}$ and 2 hours, respectively and subsequently cleared in $0.15 \mathrm{w} / \mathrm{v} \%$ trichloroacetic acid in ethanol: chloroform 4:1 v/v for 1 day (Hückelhoven et al., 1999). Cleared samples were washed with water and placed in $50 \%$ glycerol prior to be ready for evaluation. Discoloration of leaves quantified using nicked eyes or a Chemilmager 4000 digital imaging system (Alpha Innotech Corp., San Leandro, USA). 


\section{Antioxidant enzyme activities}

For enzyme assays in plants, $0.5 \mathrm{~g}$ fresh treated wheat leaf material of each particular treatment was homogenized at $0-4^{\circ} \mathrm{C}$ in $3 \mathrm{ml}$ of $50 \mathrm{mM}$ Tris buffer ( $\mathrm{pH} 7.8)$, containing $1 \mathrm{mM}$ EDTA-Na2 and 7.5\% polyvinyl pyrrolidone. The homogenates were centrifuged $\left(12,000 \mathrm{rpm}, 20 \mathrm{~min}, 4^{\circ} \mathrm{C}\right)$ and the total soluble enzyme activities were measured spectrophotometrically in the supernatant (Hafez, et al., 2014b). All measurements were carried out at $25^{\circ} \mathrm{C}$, using the model UV-160A spectrophotometer (Shimadzu, Japan).

\section{Superoxide dismutase (SOD; EC 1.15.1.1) activity}

Activity of SOD was measured in a plate reader with modifications of Mishra et al., (1993). $290 \mu \mathrm{L}$ of a mixture containing $100 \mathrm{mM}$ potassium phosphate buffer ( $\mathrm{pH}$ 7.8), $0.1 \mathrm{mM}$ EDTA, $11 \mu \mathrm{M}$ cytochrome-c, $11 \mu \mathrm{M}$ xanthine, and 0.002 Units of xanthine oxidase to $20 \mu \mathrm{g}$ of protein extracts. Xanthine oxidase controls produce an increase in the absorbance due to the reduction of cytochrome-c in the range of $0.025 \pm 0.005 \mathrm{~min}^{-1}$. Activity of SOD was expressed in units as described by McCord and Fridovich(1969).

Catalase activity (CAT; E.C. 1.11.1.6)

Activity of CAT was determined according to Aebi (1984). Decomposition of $\mathrm{H}_{2} \mathrm{O}_{2}$ by catalase results in the decrease of the ultraviolet absorption of hydrogen peroxide at $240 \mathrm{~nm}$. Enzyme activity can be calculated from this decrease. The reaction mixture contained, in a final volume of $2.15 \mathrm{ml}, 2 \mathrm{ml} 0.1 \mathrm{M} \mathrm{Na}$-phosphate buffer ( $\mathrm{pH} \mathrm{6.5),} 100 \mu \mathrm{l}$ hydrogen peroxide and $50 \mu$ leaf extract supernatant. The solution is mixed, and then the absorption change is registered for $3 \mathrm{~min}$ at $240 \mathrm{~nm}$ using a quartz cuvette.

\section{Peroxidase activity (POX; EC 1.11.1.7)}

Activity of POX was determined according to procedure proposed by Hammerschmidt et al., (1982). The reaction mixture consisted of $2.9 \mathrm{ml}$ of a $100 \mathrm{mM}$ sodium phosphate buffer $(\mathrm{pH} 6.0)$ containing $0.25 \%(\mathrm{v} / \mathrm{v})$ guaiacol (2-methoxy phenol) and $100 \mathrm{mM} \mathrm{H}_{2} \mathrm{O}_{2}$. The reaction was started by adding $100 \mu \mathrm{l}$ of crude enzyme extract. Changes in absorbance at $470 \mathrm{~nm}$ were recorded every $30 \mathrm{sec}$ intervals for $3 \mathrm{~min}$. Enzyme activity was expressed as increase in absorbance $\min ^{-1} \mathrm{~g}^{-1}$ fresh weight.

\section{Electrolyte leakage assay}

Twenty leaf discs $\left(1 \mathrm{~cm}^{2}\right)$ of wheat leaves were placed individually into flasks each contained $25 \mathrm{ml}$ deionized water (Milli-Q 50, Millipore, Bedford, Mass., USA). Flasks were shaken for $20 \mathrm{hr}$ at ambient temperature to facilitate electrolyte leakage from injured tissues. Initial electrical conductivity measurements were recorded for each vial using an Acromet AR20 electrical conductivity meter (Fisher Scientific, Chicago, IL). Flasks were then immersed in a hot water bath (Fisher Isotemp, Indiana, PA) at $80^{\circ} \mathrm{C}\left(176^{\circ} \mathrm{F}\right)$ for $1 \mathrm{hr}$ to induce cell rupture. The vials were again placed on the Innova 2100 platform shaker for $20 \mathrm{hr}$ at $21^{\circ} \mathrm{C}\left(70^{\circ} \mathrm{F}\right)$. Final conductivity was measured for each flask. Electrolyte leakage Percentage for each bud was calculated as: initial conductivity/final conductivity $\times 100 \mathrm{M}$ according to Szalaiet al. (1996). 


\section{Concentration of chlorophyll $a$ and $b$}

Chlorophyll (Chl.) concentration as $\mathrm{mg} / \mathrm{g}$ fresh weight of one gram fresh leaves was extracted with $5 \mathrm{ml} \mathrm{N}, \mathrm{N}$-dimethyl-formamid for overnight at $5^{\circ} \mathrm{C}$ then estimated Chl. a and b spectrophotometerically at 663 and $647 \mathrm{~nm}$ as described by Moran and Porath (1982). The concentrations were calculated in the following equations: $\mathrm{Chl} . a=12.76 \mathrm{~A}_{663}-2.79 \mathrm{~A}_{647}(\mathrm{mg} / \mathrm{g}$ fresh weight), Chl. $b=20.76 \mathrm{~A}_{647}-4.62 \mathrm{~A}_{663}$ (mg/g fresh weight).

\section{Scanning Electron Microscopic examination}

Anatomical structure of susceptible and resistant wheat leaves was investigated with scanning electron microscope (SEM). Wheat leaves were taken $\left(4 \mathrm{~mm}^{2}\right)$ from susceptible and resistant leaves and immediately fixed in glutraldhyde $(2.5 \%)$ for $24 \mathrm{hrs}$ at $4^{\circ} \mathrm{C}$, then post-fixed in osmium tetraoxide (1\% OS04) for one hour at room temperature (Harley and Fergusen, 1990). Samples were dehydrated with passing through ascending concentrations of acetone $(30-100 \%)$. Samples were dried till the critical point finally, leaf was sputter coated with gold. The examination and photographing were done through a Jeol Scanning Electron Microscopy (T.330 A).

\section{Detection of $P m 38$ resistant gene}

\section{DNA extraction}

Total DNA of wheat seedlings was extracted from $60 \mathrm{mg}$ of fresh leaves which initially were mashed in liquid nitrogen with a mortar and pestle using Invisorb $®$ Spin Plant Mini Kit (STRATEC Molecular, Germany) according to manufacturer's instructions.

\section{Conditions and amplification of PCR:}

Amplification of Pmregions were conducted in an automated thermal cycler $\left(\mathrm{C} 1000^{\mathrm{TM}}\right.$ Thermal Cycler, Bio-RAD) using the primer sequences of Pm38 gene (L34DINT9-R11), primers are listed as follows as mentioned by Lagudah et al., (2009). (F5'TTGATGAAACCAGTTTTTTTTCTA3' and R5'GCCATTTAACATAATCATGATGGA 3') with one cycle pre-denaturation at $94^{\circ} \mathrm{C}$ for $3 \mathrm{~min}$. Amplification step: (30 cycles ): $94^{\circ} \mathrm{C}, 300 \mathrm{sec}$ for denaturation., $48^{\circ} \mathrm{C}, 60 \mathrm{sec}$ for annealing, $72^{\circ} \mathrm{C}, 60 \mathrm{sec}$ for extension \& final extension at $72^{\circ} \mathrm{C}, 5 \mathrm{~min}$. Each PCR mixture for $\mathrm{Pm}$ genes detection $(25 \mu \mathrm{l})$ was prepared as follow, $(1 \mu \mathrm{l})$ of $25 \mathrm{ng}$ nucleic acid, $1 \mu \mathrm{l}$ of each primer (10 $\mathrm{pmol}),(12.5 \mu \mathrm{l})$ of GoTag ${ }^{\circledR}$ Colorless Master Mix (Promega Corporation, USA) and $9.5 \mu \mathrm{l}$ of Nuclease free water (Promega). $15 \mu \mathrm{l}$ of all PCR products were analyzed by electrophoresis through a $1.5 \%$ agarose gel, stained with ethidium bromide, and DNA bands were visualized using a UV transilluminator.

\section{Statistical analysis}

Two experiments were conducted during two seasons in a complete randomized design with three replicates for each treatment. Data represent the mean $\pm S D$. Student's t-test was used to determine whether significant difference $(P<0.05)$ existed between mean values according to O'Mahony (1986). 


\section{RESULTS AND DISCUSSION}

Infection types of inoculated wheat cultivars with B. graminis f. sp. tritici

According to the results during the two successive growing seasons (2012-2013 and 2013-2014) presented in table 2, the infection types of wheat powdery mildew on wheat cultivars inoculated with $B$. graminis f. sp. tritici showed great differences between all tested cultivars. Sakha 93, Sakha 94, Sids 12 and Sids 13 cultivars revealed the infection types of the susceptibility (S). Giza 160 cultivar was moderately susceptible (MS). Giza 168, Giza171 and Misr 1 were moderately resistant (MR). Misr1 and Gemmiza 11 cultivars exhibited resistance $(R)$ and highly resistance infection types, respectively (Table 3). These results agreed with the results obtained by Abdelaal et al., (2014) which showed a series types of infection in wheat cultivars infected with Puccinia striiformis.

Table (3): Infection types of B. graminis f. sp. tritici on wheat cultivars

\begin{tabular}{|c|c|c|c|c|c|}
\hline \multirow{2}{*}{ No. } & \multirow{2}{*}{ Wheat cultivars } & \multicolumn{2}{|c|}{ 2012-2013 season } & \multicolumn{2}{|c|}{ 2013-2014 season } \\
\hline & & Seedling & Adult & Seedling & Adult \\
\hline 1 & Sakha -93 (S) & 4 & 9 & 3 & 9 \\
\hline 2 & Sakha -94 (S) & 3 & 7 & 4 & 6 \\
\hline 3 & Sids $12(\mathrm{~S})$ & 4 & 7 & 3 & 6 \\
\hline 4 & $\begin{array}{c}\text { Sids } 13(\mathrm{~S}) \\
13\end{array}$ & 4 & 7 & 3 & 6 \\
\hline 5 & Giza 160 (MS) & 3 & 4 & 2 & 3 \\
\hline 6 & Giza -168 (MR) & 1 & 3 & 2 & 2 \\
\hline 7 & Giza -171 (MR) & 1 & 3 & 2 & 2 \\
\hline 8 & Misr 1 (MR) & 1 & 12 & 1 & 2 \\
\hline 9 & Misr 2 (R) & 1 & 1 & 1 & 2 \\
\hline 10 & Gem. 11 (HR) & 0 & 0 & 0 & 1 \\
\hline
\end{tabular}

\section{Disease severity of inoculated wheat cultivars}

When, susceptible and resistant wheat cultivars inoculated with wheat powdery pathogen $B$. graminis $\mathrm{f}$. sp. tritici, the disease severity percentage (Fig. 1) was highly significantly reduced in Gemmiza 11 and Misr 2 compared to Sakha 93, Sakha 94, Sids 12 and Sids 13 cultivars which showed the susceptibility to $B$. graminis f.sp. tritici. Disease severity percentage (Fig. 1) was significantly reduced also in Giza 160, Giza 168, Giza 171 and Misr 1 compared to the susceptible cultivars. It seems that the disease severity percentage was concomitant with the degree of infection types during the first season and the second season. Similar results were obtained when susceptible and resistant wheat cultivars infected with Puccinia striiformis fungus (Abdelaal et al., 2014). 

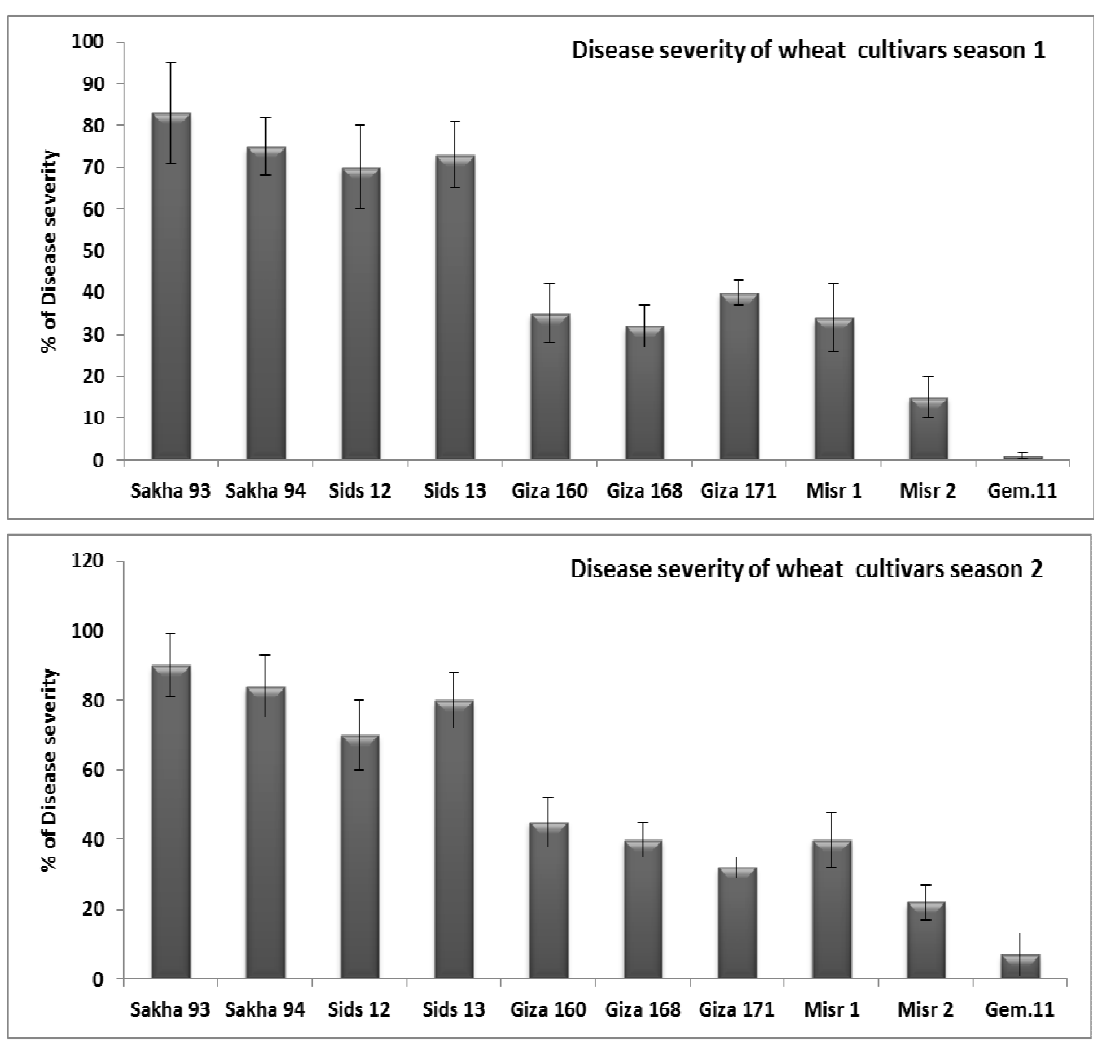

Fig. (1): Disease severity percentage of susceptible and resistant wheat cultivars inoculated with Blumeria graminis f. sp. tritici during 2012-2013 (season 1) and 2013-2014 (season 2) seasons. Sakha 93, Sakha 94, Sids 12 and Sids 13: susceptible wheat cultivars. Giza 160: moderately susceptible cultivar. Giza168, Giza 171 and Misr 1: moderately resistance cultivars. Misr 2: resistant cultivar. Gem. 11: Gemmiza 11, highly resistant cultivar.

\section{Disease symptoms of inoculated wheat cultivars}

As a result of inoculated susceptible and resistant wheat cultivars with $B$. graminis $\mathrm{f}$. sp. tritici fungus, the disease symptoms significantly appeared on Sakha 93, Sakha 94, Sids 12 and Sids 13 cultivars which showed the mycelium growth of the fungus compared with Gemmiza 11 and Misr 2 resistant cultivars (Fig. 2). Weak disease symptoms also were appeared on Giza 160, Giza 168, Giza 171 and Misr 1 compared to susceptible cultivars. The disease symptoms seem also correlated with the degree of susceptibility and resistance. These results can be supported with the results obtained by Hafez et al., (2014a) which conducted with wheat cultivars infected with wheat leaf rust Puccinia triticina. 


\section{Levels of reactive oxygen species (ROS) in inoculated wheat cultivars}

Histochemical staining of ROS mainly hydrogen peroxide $\left(\mathrm{H}_{2} \mathrm{O}_{2}\right)$ and superoxide $\left(\mathrm{O}_{2}\right)$ were visualized as brown and purple discoloration respectively. Accumulation of $\mathrm{H}_{2} \mathrm{O}_{2}$ and $\mathrm{O}_{2}$ were significantly increased in resistant and moderately resistant wheat cultivars early 6 hours after inoculation (hai) compared to the susceptible cultivars (Fig. 3). The strong brown and purple discoloration intensity indicated high levels of $\mathrm{H}_{2} \mathrm{O}_{2}$ and $\mathrm{O}_{2}{ }^{-}$ , respectively (Fig 3 ).

Quantification of discoloration of wheat leaves resulted by DAB or NBT staining indicated that levels of ROS was significantly elevated in resistant and moderately resistant cultivars compared to susceptible cultivars 6,12 and 18 hai then decreased at 24 and 48 hai (Fig. 4).

Enhanced ROS production in plants is termed 'oxidative burst' (Wojtaszek, 1997). ROS appeared continuously in the chloroplasts by partial reduction of $\mathrm{O}_{2}$ molecules or energy transfer to them during the duration of photosynthesis. The production of ROS is an inevitable consequence of aerobic respiration. When the terminal oxidases-cytochrome oxidase and the alternative oxidase react with $\mathrm{O}_{2}$, four electrons are transferred and $\mathrm{H}_{2} \mathrm{O}$ is released. It has been noted that $\mathrm{O}_{2}$ is usually the first ROS to be generated.

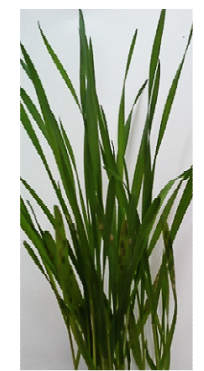

Sakha 93

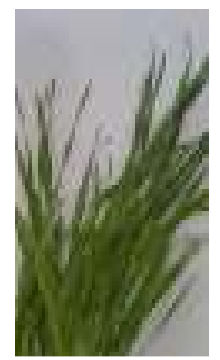

Giza 168

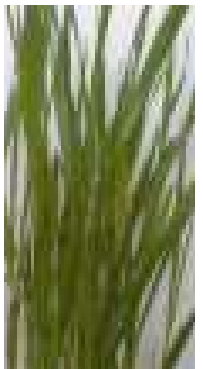

Sakha 94

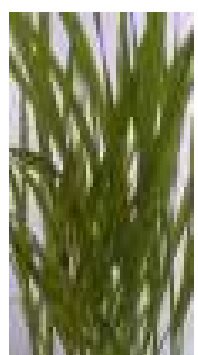

Giza 171

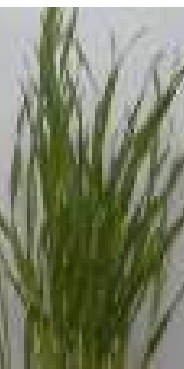

Sids 12

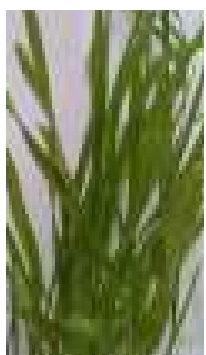

Misr 1

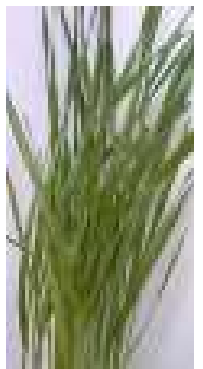

Sids 13

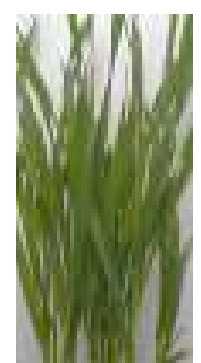

Misr 2

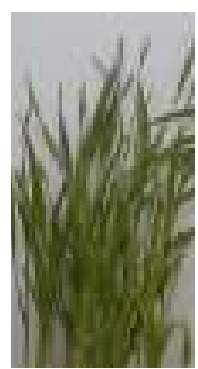

Giza 16

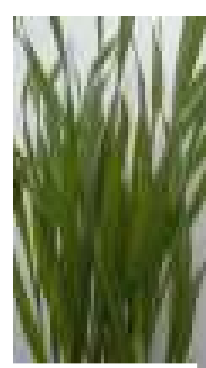

Gim. 11

Fig. (2): Disease symptoms on susceptible and resistant wheat cultivars inoculated with wheat powdery mildew B. graminis f. sp. tritici 5 days after inoculation. 
In plant tissues, about $1-2 \%$ of $\mathrm{O}_{2}$ consumption leads to the generation of $\mathrm{O}_{2}{ }^{-}$. $\mathrm{ROS}$ derived from the oxidative burst can directly damage bacteria (Molina-Cruz et al., 2008) and can also function as signaling molecules (Atia et al., 2005). In plant cells, for example, ROS derived from the stressinduced oxidative burst activate a variety of defense responses including synthesis of phytoalexins, synthesis of pathogenesis-related proteins, and suppression of pathogen growth by programmed cell death (Lamb and Dixon, 1997). It has been well established that excess of $\mathrm{H}_{2} \mathrm{O}_{2}$ in plant cells leads to the occurrence of oxidative stress (Atia et al., 2005, Hafez et al., 2012; Hafez et al., 2014a).

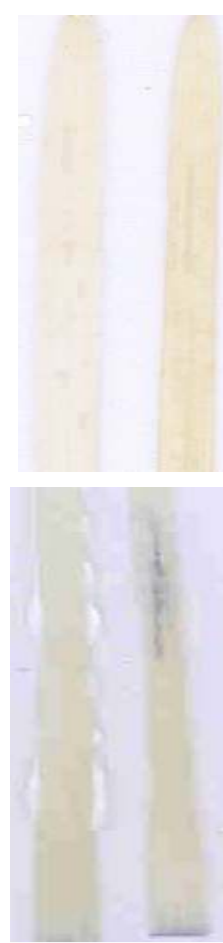

S. 93
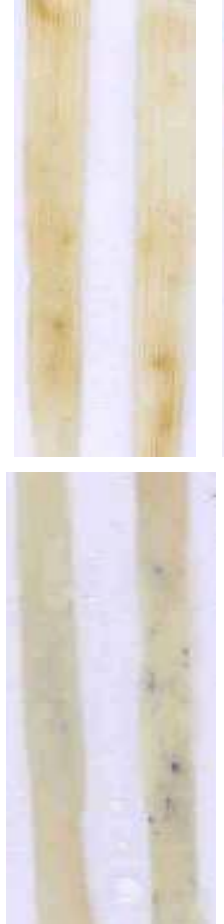
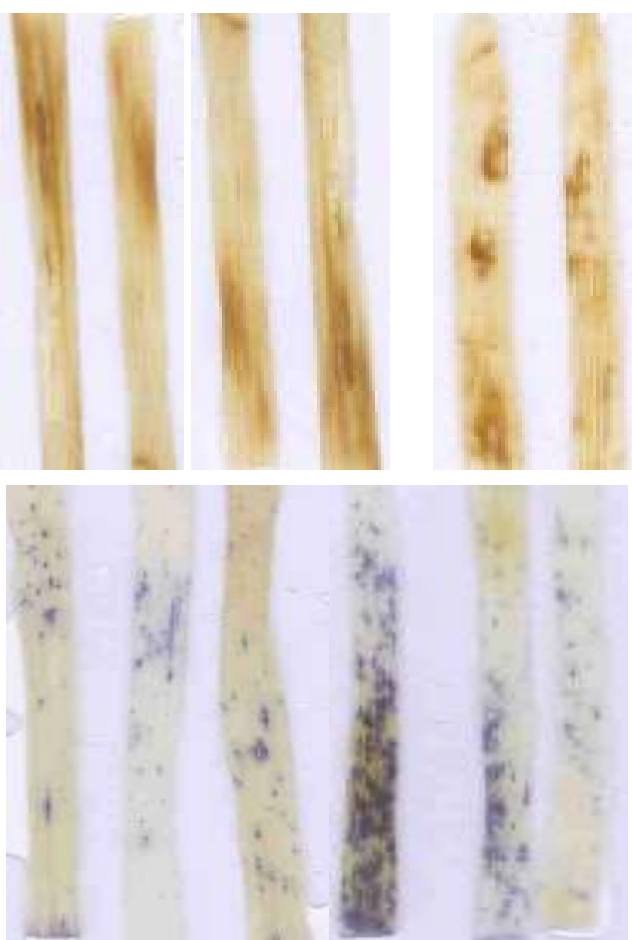

S. 94

Sids 12 Sids 13 G.160

G. 168

G. 171

Fig. (3): Accumulation of reactive oxygen species (ROS), purple discoloration of superoxide (lower row) and brown discoloration of hydrogen peroxide (upper row) in susceptible and resistant wheat cultivars 6 hours after inoculated with wheat powdery mildew B. graminis f. sp. tritici. 

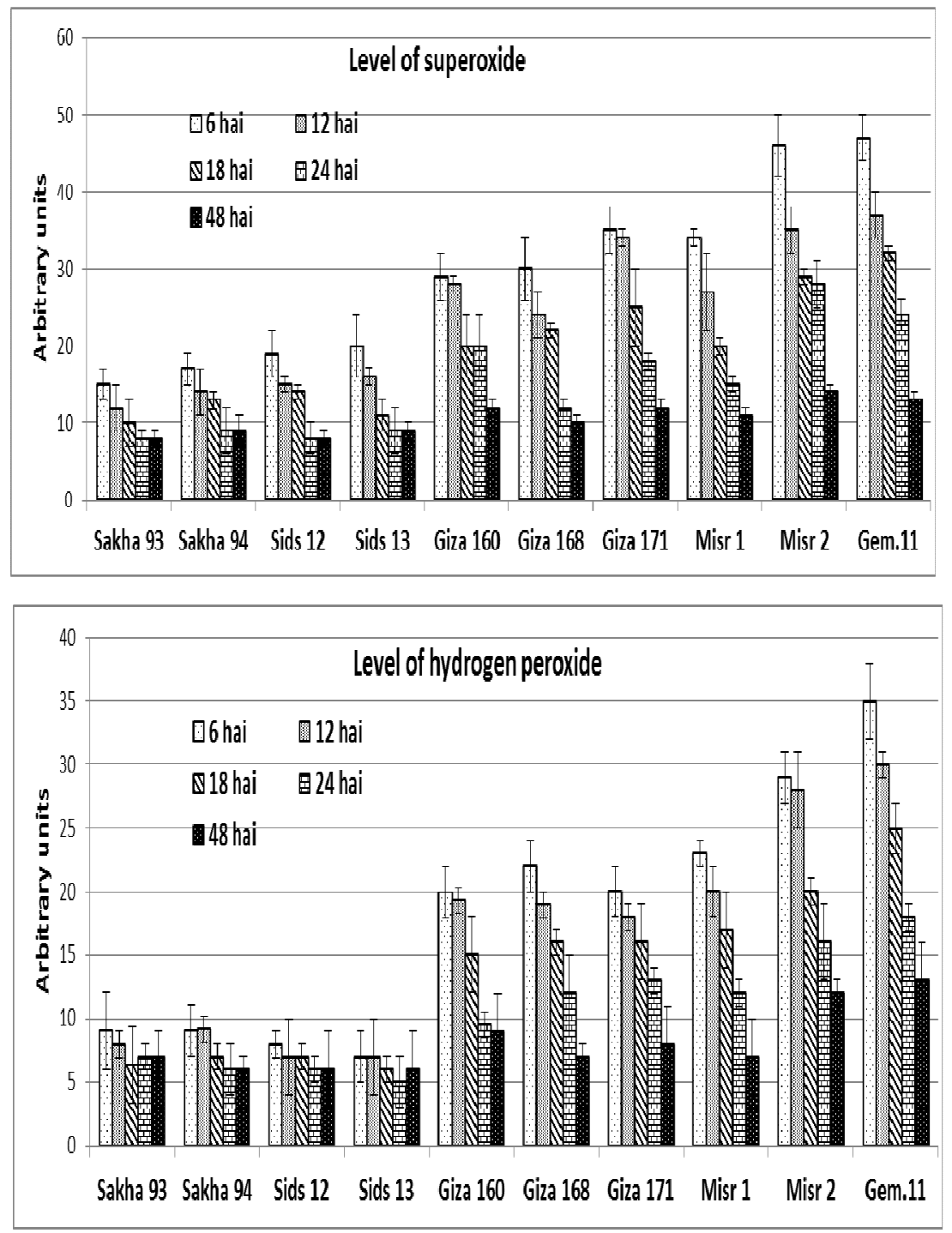

Fig. (4): Levels of superoxide (upper) and hydrogen peroxide (lower) in susceptible and resistant wheat cultivars inoculated with wheat powdery mildew B. graminis f. sp. tritici 6, 12, 18, 24 and 48 hours after inoculation. 
These results showed early elevated levels of $\mathrm{H}_{2} \mathrm{O}_{2}$ and $\mathrm{O}_{2}{ }^{--}$in the resistant wheat cultivars lead to less damage in the cells. Levels of $\mathrm{ROS}$ were increased when antioxidants were decreased. Similarly, in resistant Egyptian and other wheat cultivars inoculated with leaf rust (Puccinia triticina), $\mathrm{H}_{2} \mathrm{O}_{2}$ has a key role in resistance (Atia et al., 2005; Hafez et al., 2009). Similar results were obtained in susceptible and resistant wheat cultivars inoculated with Puccinia striiformis the causal agent of strip rust (Abdelaal et al., 2014). ROS are elevated also when the host plant infected with phytoplasma (Musetti et al., 2005; Sanchez-Rojo et al., 2011) and plant treated with inducers of resistance substances (Atia et al., 2005). Consequently, it is important for bacterial pathogens to suppressing ROS by activation of antioxidant enzymes for their survival (Halliwell, 1974).

\section{Activity of antioxidant enzymes in inoculated wheat cultivars}

According to the results, up-down regulation of antioxidant enzymes activities were expected particularly, SOD, CAT and POX could be upregulated. The activities of antioxidant enzymes in susceptible and resistant wheat cultivars inoculated with wheat powdery mildew fungus were undertaken. SOD plays a major role in the degradation and dismutation processes of superoxide in ROS detoxification pathways (Fridovich, 1995). Superoxide dismutase (SOD), catalase (CAT) and peroxidase (POX) activities in wheat susceptible and resistant cultivars were a little bit increased early 6 , 12 and 18 hai with wheat powdery mildew pathogen (Fig. 5). However, the activities of these enzymes were significantly increased in resistant and moderately resistant wheat cultivars compared to susceptible cultivars 24,48 and 72 hai (Fig. 5). It is clearly known that the first response following the oxidative burst is the stimulation of ROS scavenging enzymes. SOD is usually considered the first line of defense against oxidative stress (Dewir, 2001). Antioxidant defense systems are enzymatic and non-enzymatic antioxidants. Enzymatic antioxidants include superoxide dismutase (SOD), catalase (CAT), peroxidase (POX), ascorbate peroxidase (APX) and polyphenol oxidase (PPO). The non-enzymatic antioxidants are glutathione (GSH), carotenoids and tocopherols. The up-regulation of CAT, POX and PPO plays vital role during elevated the ROS levels. So,, protected resistant wheat cultivars from pathogen attack. Similarly, tobacco plants protected against viral, bacterial and fungal infections (Hafez et al., 2012; Abdelaal et al., 2014; Hafez et al., 2014a; Hafez et al., 2014b).

$\mathrm{H}_{2} \mathrm{O}_{2}$ plays central role in the oxidative burst, acting as a signal for the localized death of challenged cells (Martinez et al., 2000; Atia et al., 2005) and as a diffusible signal for the induction of cellular protective genes in adjacent healthy cells and tissues (Levine et al., 1994). $\mathrm{H}_{2} \mathrm{O}_{2}$ generated by SOD is further degraded and detoxified by other antioxidant enzymes such as POX, APX or CAT. Previous reports demonstrated that POX and PPO may participate in the responding defense reaction by inducing plant resistance against pathogenic agents (Ray et al., 1998). 

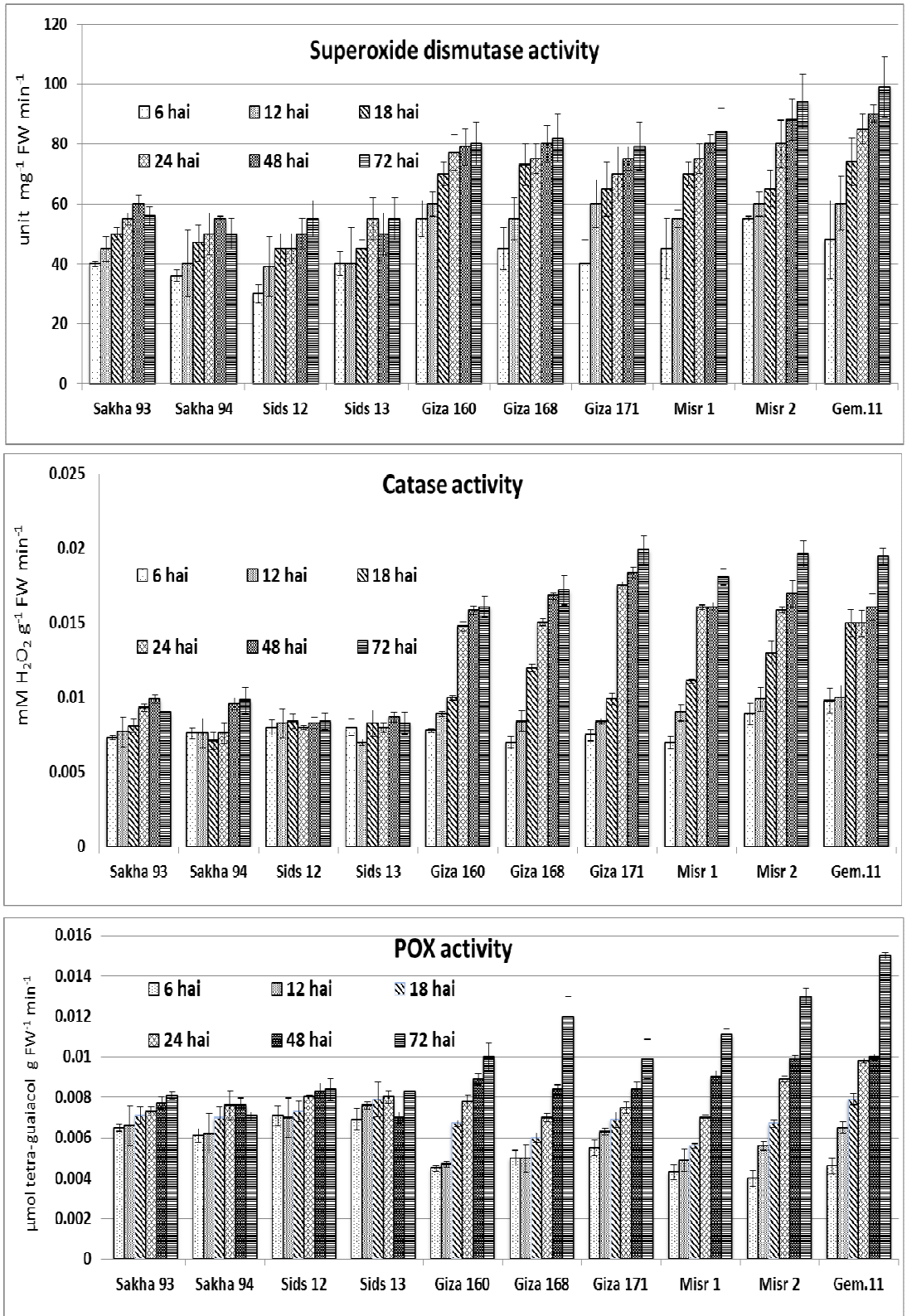

Fig. (5): Activities of antioxidant enzymes superoxide dismutase (SOD), catalase (CAT) and peroxidase (POX) in susceptible and resistant wheat cultivars inoculated with wheat powdery mildew fungus $B$. graminis f. sp. tritici $6,12,18,24,48$ and 72 hours after inoculation. 


\section{Electrolyte leakage in inoculated wheat cultivars}

Electrolyte leakage (EL) constitutes as an indicator of the membrane permeability. It was significantly increased in all susceptible wheat cultivars inoculated with $B$. graminis f. sp. tritici compared to the resistant or even the moderately resistant cultivars (Fig. 6). The cellular membrane dysfunction due to stress is well increased permeability and leakage of ions out, which can be readily measured by the efflux of electrolytes. Increase of cell permeability is one of the most common effects of pathogens on the plant cells. Electrolyte leakage has been used to quantify damages of cell membranes in response to biotic stresses (Adam et al., 2000; Sriram et al., 2000; Hafez et al., 2014a; Abdelaal et al., 2014) as well as a biotic stresses (Pearce, 2001; Zhou et al., 2005; Abbas, 2012).

In the present study, inoculation B. graminis f. sp. tritici increased electrolyte leakage in susceptible wheat cultivars than the resistant cultivars because it is an obligatory parasite which depends heavily on their host cells for essential metabolic compounds, this could be because of pathogen-host compatibility. These results supported by results which chemical compounds and biotic or a biotic stresses could alter the resistance or susceptibility of plants to infection through their effects on membrane permeability (Hafez et al., 2014b). It is known that ethylene affects membrane permeability (Goodman et al., 1986). Similarly, high temperature stress could induce susceptibility in maize through its effects on membrane permeability as measured by increased electrolyte leakage (Garraway et al., 1989). This might results in the loss of host cells' constituents which may be used by the invading pathogen as a source of nutrients.

These results indicated that resistance of some wheat (cultivars) protected cell membranes during the pathogen attack, while the cell membrane of the susceptible cultivars was affected by the pathogen inoculation and lost its constituents. The present results are in agreement with those obtained by (Houimli et al., 2010; Hafez, et al., 2014b).

\section{Chlorophyll a and $b$ concentrations}

Chlorophyll $a$ and $b$ concentrations increased in all the resistant (Gemmiza 11 and Misr 2), moderately resistant (Giza 168, Giza 171, Misr 1) and moderately susceptible (Giza 160) wheat cultivars compared to the susceptible cultivars (Sakha 93, Sakha 94, Sids 12, Sids 13) during both seasons (Fig. 7).

It seems that high concentrations of chlorophyll a and b correlated with the degrees of resistance (Fig. 7). Similar results obtained by Abdelaal et al., (2014), Moriondo et al., (2005) and Lindenthal et al., (2005) in wheat cultivars inoculated with stripe rust Puccinia striiformis and squash plants infected with downy mildew On the other hand, chlorophyll a/b decreased in susceptible cultivars. This could be correlated with genes encoding chlorophyll a/bbinding proteins which responsive to powdery mildew infection (Xin et al., 2012). It was found 32 genes encoding chlorophyll a/b-which responsive to powdery mildew infection, only two of them were up-regulated, while the others were repressed in susceptible than in resistant wheat genotype using microarray (Xin et al., 2012). The decreased of chlorophyll concentration perhaps due to the spread of the pathogen hypha and its penetration in host 
cells by haustoria are thought to destabilize the structural integrity, which reduces chlorophyll pigments in wheat infected with rust disease (Lindenthal et al., 2005 and Abdelaal et al., 2014).

The reduction of chlorophyll is might be due to the decrease in the number and abnormal form of chloroplasts in the mesophyll tissue. Chlorophyll concentration was decreased gradually with the increase in disease severity (Mandal et al., 2009 and Abdelaal et al., 2014).

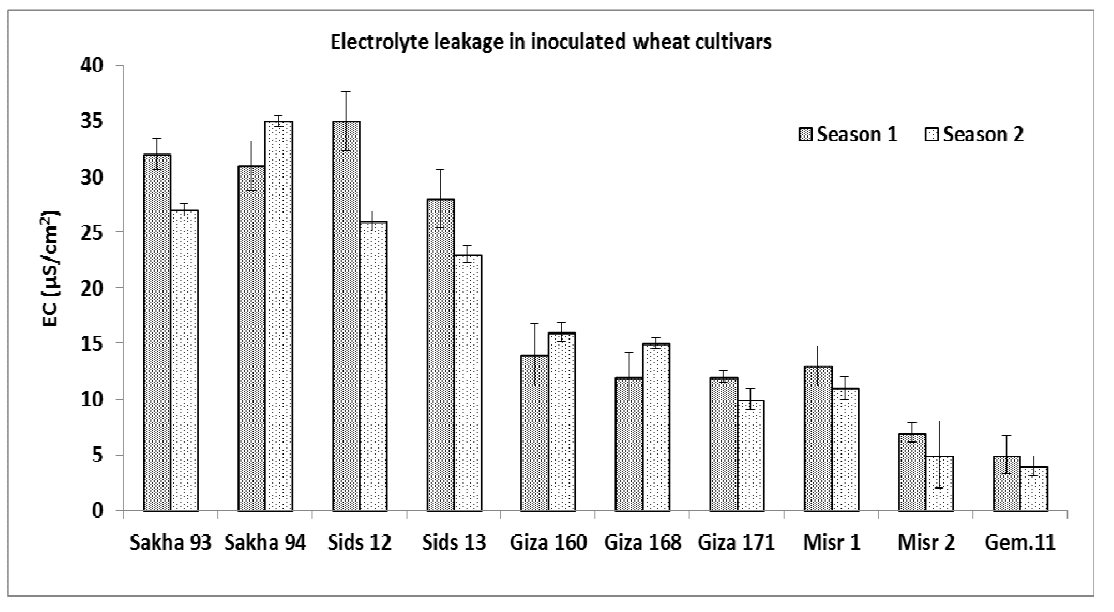

Fig. (6): Electrolyte leakage in susceptible and resistant wheat cultivars 72 hours after inoculation with wheat powdery mildew $B$. graminis f. sp. tritici during 2012-2013 (season 1) and 20132014 (season 2) seasons.

Histological alterations of wheat inoculated with $B$. graminis f. sp. tritici

The inoculated susceptible wheat cultivars Sakha -93, Sakha -94, Sids

12, Sids 13 were colonized extensively by $B$. graminis f. sp. tritici and producing much conidiophores and large amounts of conidia spores (Fig. 8 a, b, c and d). Similar results were recorded by Abdelaal et al., (2014). On the other hand, in moderate susceptible cultivars such as Giza 160, Giza 168 (Fig.8 e and f) and in moderate resistant cultivars such as Giza 171 and Misr 1 (Fig. $8 \mathrm{~g}$ and $\mathrm{h}$ ) the fungus were colonized only in a limited extent, producing a very little number of conidia spores specially in moderate resistant cultivars (Fig.8 $\mathrm{g}$ and $\mathrm{h}$ ). In the resistant cultivar such as Misr 2 and highly resistant cultivar such as Gemmiza11 (Fig.8 $\mathrm{i}$ and $\mathrm{j}$ ) the fungus did not show colonies or spores on the leaves during this study. 

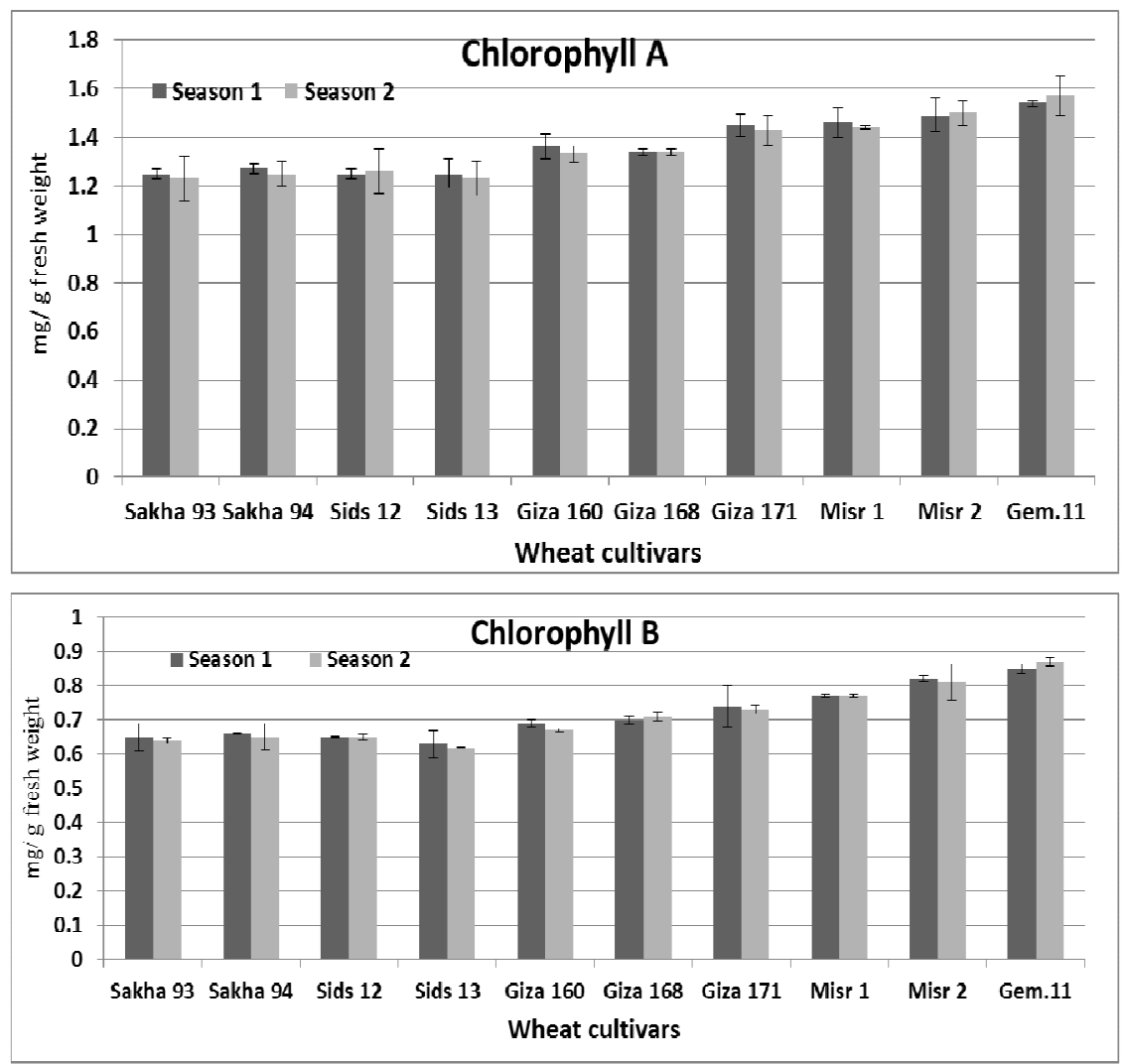

Fig. (7): Chlorophyll a (upper diagram) and chlorophyll b (lower diagram) concentrations in susceptible and resistant wheat cultivars 72 hours after inoculation with wheat powdery mildew $B$. graminis f. sp. tritici during 2012-2013 (season 1) and 20132014 (season 2) seasons. 


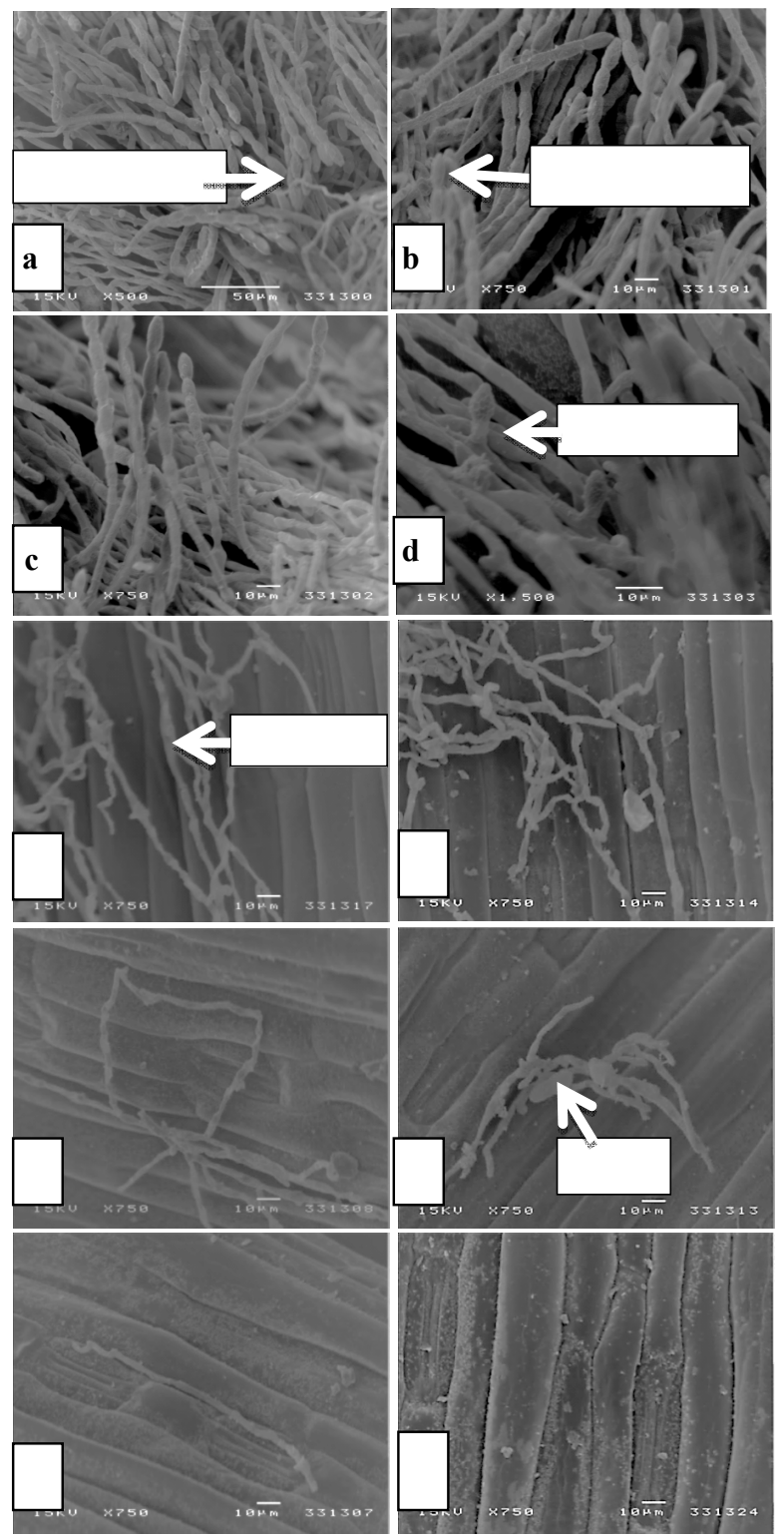

Fig. (8): Fungal development and host cell responses by SEM in susceptible and resistant wheat cultivars inoculated with Blumeria gramins f. sp. tritici. a. Sakha 93 susceptible cultivar, b. Sakha 94 susceptible cultivar, c. Sids 12 susceptible cultivar, d. Sids-13 susceptible, e. Giza 160 moderate susceptible f. Giza 168 moderate resistant, g. Giza 171 moderate resistant, $h$. Misr 1 moderate resistant, i. Misr 2 resistant cultivar, j. Gem.11 highly resistant cultivar; Bar = $10 \mu \mathrm{m} ., \quad B a r=50 \mu \mathrm{m}$. 


\section{Accumulation of $P m 38$ gene in wheat cultivars:}

In resistant wheat cultivars inoculated with $B$. graminis f. sp. tritici, Pm38 gene was significantly accumulated compared to the susceptible cultivars (Fig. 9). Wheat plants have six chromosomal (A, B, D) in which could play partial role in increasing the DNA amount, therefore increasing Pm38 copies in the resistant genome. The Yr18/Lr34/Pm38 locus confers partial and durable adult plant resistance (APR) against leaf rust, stripe rust and powdery mildew of wheat (Lagudah et al., 2009). Pm38 resistant gene over accumulated in resistant cultivars and perhaps play an important role together with the early accumulation of ROS mainly $\mathrm{O}_{2}{ }^{--}$and $\mathrm{H}_{2} \mathrm{O}_{2}$ in which stimulate the activities of SOD, CAT and POX enzymes together. Similarly, Feng et al., (2014) and Abdelaal et al., (2014) found similar results.

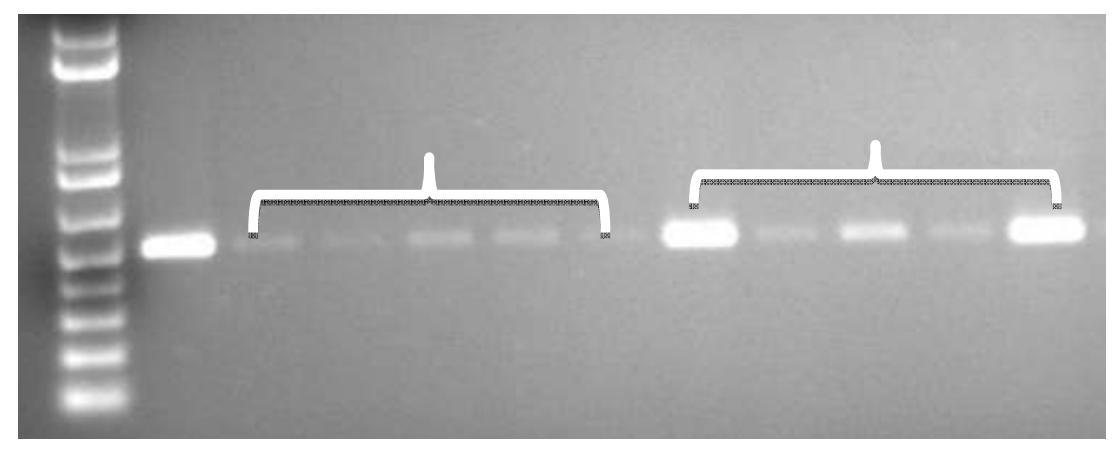

Fig. (9): Accumulation of pm38 resistant gene in 10 wheat cultivars inoculated with fungus $B$. graminis f.sp. tritici. Ladder: $100 \mathrm{bp}$ size ladder. Pm38: monogenic line. S: susceptible cultivars (Sakha 93, Sakha 94, Sids 12, Sids 13). MS: moderately susceptible cultivar (Giza 160). MR: moderately resistant cultivars (Giza 168, Giza 171, Misr 1). R: resistant cultivar (Misr 2). HR: highly resistant cultivar (Gemmiza 11).

It could be concluded that the disease severity of powdery mildew of wheat and symptoms were reduced and suppressed respectively, in the resistant wheat cultivars as well as high concentration of chlorophyll $a / b$ correlated as a result of the Pm38 resistant gene and ROS early accumulation which perhaps increased the enzyme activities and decreased electrolyte leakage compared to the susceptible cultivars. 


\section{Aknowledgement}

This laboratory research was conducted in Plant Pathology and Biotechnology Lab., (under accreditation of ISO/17025) and EPCRS Excellence Centre, Dept. of Agric. Botany, Fac. of Agric., Kafr-Elsheikh University, Egypt. The EPECRS Excellence Centre Project funded by Management Supporting Excellence (MSE), Development Projects Management Unit, Ministry of Higher Education, Egypt.

\section{REFERENCES}

Abbas, S.M., (2012). Effects of low temperature and selenium application on growth and the physiological changes in sorghum seedlings. J. Stress Physiol. Biochem., 8: 268-286.

Abdelaal, Kh.A.A.; Y.M. Hafez; Samar M. Adel; W.A. Youseef; and M.M. Badr (2014). Biochemical, histological and molecular changes in some Egyptian wheat varieties infected with stripe rust (Pucciniastriiformis $\mathrm{f}$. sp. tritici). Egypt. J. Biol. Pest Cont., 24(2): 421-429.

Adam, A.L.; A.A. Gala;K. Manninger and B. Barna (2000). Inhibition of the development of leaf rust (Puccinia recondita) by treatment of wheat with allopurinol and production of a hypersensitive- like reaction in a compatible host. Plant Pathol., 49: 317-323.

Aebi, H. (1984). Catalase in vitro. Methods Enzymol., 105: 121-126.

Anahid F.; M. Zaeifizadeh; H. Shahbazi and M. Ghasemi (2013). Interaction between wheat cultivars and stripe rust strain on the screening of different defense strategies, Int. J. Agric. Plant Prod. 4 (10): 2598-2605.

Apel, K. and H. Hirt (2004). Reactive oxygen species: metabolism, oxidative stress and signal transduction. Annu Rev. Plant Biol. 55, 373-399.

Atia, M.M.M.; Buchenauer, H.; Aly, A.Z.; and Abou-Zaid, M.I. (2005). Chitosan induced cell death, SA, pathogenesis related-protein and active enhancement of resistance in tomato to Phytophthora infestans the late blight pathogen. J. Biological Agric., \& Horticulture, 23: 175-197

Awad, Y.M.; A.A.Abdullah; T.Y.Bayoumi; K. Abd-Elsalam and A. Hassanien (2015). Early detection of powdery mildew disease in wheat (Triticum aestivum L.) using thermal imaging technique. Advances in Intelligent Systems and Computing. 323: 755-765.

Bernardo, A. ; G. Bai; P. Guo; K. Xiao; A.C. Guenzi and P. Ayoubi (2007). Fusarium graminearum-induced changes in gene expression between Fusarium head blight-resistant and susceptible wheat cultivars. Funct. Integr. Genomics, 7:69-77.

Bhullar, N. K.; K. Street; M. Mackay; N. Yahiaoui and B. Keller (2009). Unlocking wheat genetic resources for the molecular identification of previously un-described functional alleles at the Pm3 resistance locus. Proc. Natl. Acad. Sci. USA, 106: 9519-24. 
Brunner, S.; D. Stirnweis; C. Diaz Quijano; G. Buesing; G. Herren; F. Parlange; P. Barret; C. Tassy; C. Sautter; M. Winzeler and B. Keller (2011). Transgenic Pm3 multilines of wheat show increased powdery mildew resistance in the field. Plant Biotechnol., J., 10: 398409.

Chen, X.; A.S. Marcelo; Y. Guiping; S. Jun and J. Dubcovsky (2003). Development of sequence tagged site and cleaved amplified polymorphic sequence markers for wheat stripe rust resistance gene Yr5. Crop Sci., 43: 2058-2064.

Chris, K.S. (2012). Infection biology and aggressiveness of Puccinia striiformis on Resistant and Susceptible Wheat. Ph.D. Thesis, Fac. Science and Technology, Aarhus Univ., 139 pp.

Coram, T.E.; M.L. Settles and X. Chen (2008). Transcripton analysis of hightemerature adult plant resistance conditioned by Yr39 during the wheat-Puccinia striiformis f. sp. tritici interaction. Mol. Plant Pathol., 9: 479-93.

Dewir, Y.H. (2001). Physiological responses of suspension-cultured carnation cells to gamma rays irradiation and high temperature stress. MSc Thesis, South China Agricultural University (SCAU), China.

Feng, H.; X. Wang; Q. Zhang; Y. Fu; C. Feng; B. Wang;L.Huang and Z. Kang (2014). Monodehydroascorbate reductase gene, regulated by the wheat PN-2013 miRNA, contributes to adult wheat plant resistance to stripe rust through ROS metabolism. Biochim Biophys Acta., 1839 (1):1-12.

Fridovich, I. (1995). Superoxide radical and superoxide dismutases. Annu. Rev. Biochem., 64: 97-112.

Garraway, M.O.; M. Akhtar and E.C.W. Wokoma (1989). Effect of high temperature stress on peroxidase activity and electrolyte leakage in relation to sporulation of Bipolaris maydis race T. Phytopathology, 79: 800-805.

Gechev, T.; I. Gadjev; F.VanBreusegem; D. Inzé; S. Dukiandjiev; V. Toneva and I. Minkov (2002). Hydrogen peroxide protects tobacco from oxidative stress by inducing a set of antioxidant enzymes. Cell Mol. Life Sci. 59:708-714.

Goodman, R.N.; Z. Kiraly and K.R. Wood (1986). The Biochemistry and Physiology of Plant Disease. University of Missouri Press, Columbia, MO. Pp. 433.

Griffey, C.A. (1993). Effectiveness of adult-plant resistance in reducing grain yield loss to powdery mildew in winter wheat. Plant Dis., 77:618-22.

Hafez, Y.M.; Z. Király and K. Manninger (2009). Hydrogen peroxide has a key role in resistance to leaf rust (Puccinia triticina) in several Egyptian and other wheat cultivars. Cereal Res. Commun., 37: 161-164.

Hafez, Y.M.; R. Bacso; Z. Király; A. Kunstler and L. Király (2012). Upregulation of antioxidants in tobacco by low concentrations of $\mathrm{H}_{2} \mathrm{O}_{2}$ suppresses necrotic disease symptoms. Phytopathol., 102:848-856.

Hafez, Y.M. (2013). A pivotal role of reactive oxygen species and antioxidants to attenuate Tobacco Mosaic Virus. Egyp. J. Biol. Pest Cont., 23(2): 277-285. 
Hafez, Y.M. and N. A. El-Baghdady (2013). Role of reactive oxygen species in suppression of barley powdery mildew fungus, Blumeriagraminis f.sp. hordei with benzothiadiazole and riboflavin. Egyp. J. Biol. Pest Cont., 23(1): 125-132.

Hafez, Y.M.; N. K. Soliman; M.M. Saber; I. A. Imbabi and A.S. Abd-Elaziz (2014a). Induced resistance against Puccinia triticina the causal agent of wheat leaf rust by chemical inducers. Egyptian J. Biol. Pest Cont., 24(1): 173-181.

Hafez, Y.M.;R.Y. Mourad; M. Mansour and Kh. A.A. Abdelaal (2014b). Impact of non-traditional compounds and fungicides on physiological and biochemical characters of barely infected with Blumeria graminis $\mathrm{f}$. $\mathrm{sp}$. hordei under field condtition. Egyptain J. Biol. Pest Cont. 24(2): 445453.

Halliwell, B. (1974). Oxidation of format by peroxisomes and mitochondria from spinach leaves. Biochem. J., 138: 77-85.

Halliwell, B. and J. M. C. Gutteridge (1999). Free Radicals in Biology and Medicine: Oxford University Press.

Hammerschmidt, R.; E.M. Nuckles and J. Kuć (1982). Association of enhanced peroxidase activity with induced systemic resistance of cucumber to Colletotrichum lagenarium. Physiol. Plant Pathol, 20(1):73-82.

Harley, M. M. and I. K. Ferguson (1990). The role of the SEM in pollen morphology and plant systematics. In: Claugher, D. (ed.) Scanning Electron Microscopy in Taxonomy and Functional Morphology. Sys. Assoc. Spe., pp. 45-68, Clarendon Press, Oxford.

Heath, M. (2000). Hypersensitive response related death. Plant Mole Biol.44: 321-334.Houimli, S.M.; M. Denden and B.D. Mouhandes (2010). Effects of 24-epibrassinolide on growth, chlorophyll, electrolyte leakage and proline by pepper plants under $\mathrm{NaCl}$-stress. Eur. Asia. J. Bio. Sci., 4: 96-104.

Hückelhoven, R.; J. Fodor; C. Preis and K.H. Kogel (1999). Hypersensitive cell death and papilla formation in barley attacked by the powdery mildew fungus are associated with hydrogen peroxide but not with salicylic acid accumulation. Plant Physiol., 119: 1251-1260.

Lagudah, E.S.; S.G. Krattinger; S. Herrera-Foessel; R.P. Singh; J. HuertaEspino; W. Spielmeyer; G. Brown-Guedira; L.L. Selter and B. Keller (2009). Gene-specificmarkers for the wheatgeneLr34/Yr18/ Pm38which confers resistance to multiple fungal pathogens. Theor Appl Genet 119:889-898.

Lamb, C. and R.A. Dixon (1997). The oxidative burst in plant disease resistance. Annu. Rev. Plant Physiol. Plant Mol. Biol., 48: 251-275.

Large, E. C. (1954). Growth stages in cereals: Illustration of Feekes scale PL . Pathol., 3: 128-129. 
Leath, S. andK.L. Bowen (1989).Effects of powdery mildew, triadimenolseed treatment, and triadimefon foliar sprays on yieldof winter wheat in North Carolina. Phytopathology, 79:152-5.

Leath, S. and M. Heun (1990). Identification of powdery mildew resistance genes in cultivars of soft red winter wheat. Plant Dis., 74: 747-7582.

Levine, A.; R.Tenhaken; R. Dixon and C. Lamb (1994). $\mathrm{H}_{2} \mathrm{O}_{2}$ from the oxidative burst orchestrates the plant hypersensitive disease resistance response. Cell, 79: 583-593.

Line, R.F. and X.M. Chen (1995). Successes in breeding for and managing durable resistance to wheat rusts. Plant Dis. 79: 1254-1255.

Lindenthal, M.; U. Steiner; H.W. Dehne and E.C. Oerke (2005). Effect of downy mildew development on transpiration of cucumber leaves visualized by digital infrared thermography. Phytopathol. 95: 233-240.

Ma, Q. and H.S. Shang (2009). Ultrastructure of stripe rust (Puccinia striiform f. sp. tritici) interacting with slow-rusting, highly resistant, and susceptible wheat cultivars. J. Plant Pathol., 91: 597-606.

Mandal, K.; R. Saravanan; S. Maiti and I. L. Kothari (2009). Effect of downy mildew disease on photosynthesis and chlorophyll fluorescence in PlantagoovataForsk. J. PLant Dis. Prot., 116 (4): 164-168.

Martinez, C.;J.C. Baccou; E. Bresson; Y. Bessac; J.F. Daniel;A. Jalloul; J.L. Montillet; J.P. Geiger;K. Assigbetse and M. Nicole (2000). Salicylic acid mediated by the oxidative burst is a key molecule in local and systemic response of cotton challenged by an a virulent race of Xanthomonas campestris pv. malvacearum. Plant Physiol., 122: 757-766

McCord, J.M. and I. Fridovich (1969). Superoxide Dismutase: an enzymatic reaction for erythrocuprein (hemocuprein). J. Biol. Chem., 244: 60496055.

Mishra, N.P.; R.K. Mishraand G.S. Singhal (1993). Changes in the activities of anti-oxidant enzymes during exposure of intact what leaves to strong visible light at different temperatures in the presence of protein synthesis inhibitors. Plant Physiol., 102: 903-910.

Molina-Cruz, A.;R.J. DeJong;B.Charles;L. Gupta;S. Kumar;G. JaramilloGutierrez and C. Barillas-Mury (2008). Reactive oxygen species modulate Anopheles gambiae immunity against bacteria and Plasmodium. J. Biol. Chem., 283: 3217-3223.

Moran, R. and D. Porath (1982). Chlorophyll determination in intact tissues using N,N-Dimethyl formamide. Plant Physiol., 69: 1370-1381.

Moriondo, M.; S. Orlandini; A. Giuntoli and M. Bindi (2005). The effect of downy and powdery mildew on grapevine (Vitis vinifera L.) leaf gas exchange. J. Phytopathol., 153, 350-357.

Musetti, R.; L. Sanità di Toppi; M. Martini; F. Ferrini; A. Loschi; M.A. Favali and R. Osler (2005). Hydrogen peroxide localization and antioxidant status in the recovery of apricot plants from European stone fruit yellows. Eur. J. Plant Pathol., 112: 53-61.

O'Mahony, M. (1986). Sensory Evaluation of Food: Statistical Methods and Procedures. CRC Press, p. 487. 
Peng, J.H; T. Fahima; M.S. Roder; Q.Y. Huang; A. Dahan; Y.C. Li; A. Grama and E. Nevo (2000). High-density molecular map of chromosome region harboring stripe-rust resistance genes $\mathrm{YrH} 52$ and $\mathrm{Yr} 15$ derived from wild emmer wheat, Triticumdicoccoides. Genetica (The Hague) 109: 199-210.

Ray, H.;D.S. Douches and R. Hammerschmidt (1998). Transformation of potato with cucumber peroxidase: expression and disease response. Physiol. Mol. Plant Pathol., 53: 93-103

Pearce, R.S. (2001). Plant freezing and damage. Ann. Bot., 87: 417-424.

Röbbelen, G. and E.L. Sharp (1978). Mode of inheritance, interaction and application of genes conditioning resistance to yellow rust. Fortschr. Pflanzenzücht. 9: 1-88.

Sanchez-Rojo, S.;H.A. Lopez-Delgado;M.E. Mora-Herrera;H.I. AlmeydaLeon;H.A.Zavaleta-Mancera and D. Espinosa-Victoria(2011). Salicylic acid protects potato plants from phytoplasma-associated stress and improves tuber photosynthate assimilation. Am. J. Potato Res., 88: $175-183$.

Shi, Q.M.;X.X. Zhang and X.Y. Duan(1987). Identification of isolation of Blumeria graminis f. sp. ritici. Sci. Agric. Sin., 20: 64-70.

Sriram, S.; T. Raguchander; S. Babu; R. Nandakumar;V. Shanmugam and P. Vidhyasekaran (2000). Inactivation of phytotoxin produced by the rice sheath blight pathogen Rhizoctonia solani. Can. J. Microbiol., 46: 520524.

Szalai, G.; T. Janda; E. Paldi and Z. Szigeti (1996). Role of light in postchilling symptoms in maize. J. Plant Physiol., 148: 378-383.

Wang, L.F; J.X. Ma; R.H. Zhou; X.M. Wang and J.Z. Jia (2002). Molecular tagging of the yellow rust resistance gene Yr10 in common wheat, P.I.17838 (Triticum aestivum L.). Euphytica 124: 71-73.

Wang, X.; W. Liu; X. Chen; C. Tang; Y. Dong; J. Ma; X. Huang; G. Wei; Q. Han; L. Huang and Z. Kang (2010). Differential gene expression in incompatible interaction between wheat and stripe rust fungus revealed by CDNA-AFLP and comparison to compatible interaction. BMC Plant Biol. 10:9-15

Wilson, C. L.; A. El-Ghaouth; E. Chalutz; S. Droby; C. Stevens; J.Y. Lu; V. Khan and J. Arul (1994). Potential of induced resistance to control postharvest diseases of fruits and vegetables. Plant Dis., 78: 837-842.

Wojtaszek, P. (1997). Oxidative burst: an early plant response to pathogen infection. Biochem. J., 322: 681-692.

Xin, M.; X. Wang; H. Peng;Y. Yao;C. Xie;Y. Han;Z. Ni andQ. Sun (2012).Transcriptome comparison of susceptible and resistant wheat in response to powdery mildew infection. Genomics Proteomics Bioinformatics, 10: 94-106.

Zhou, B.;Z. Guoand Z. Liu (2005). Effects of abscisic acid on antioxidant systems of Stylosanthesguianensisunder chilling stress. Crop Sci., 45: 599-605. 


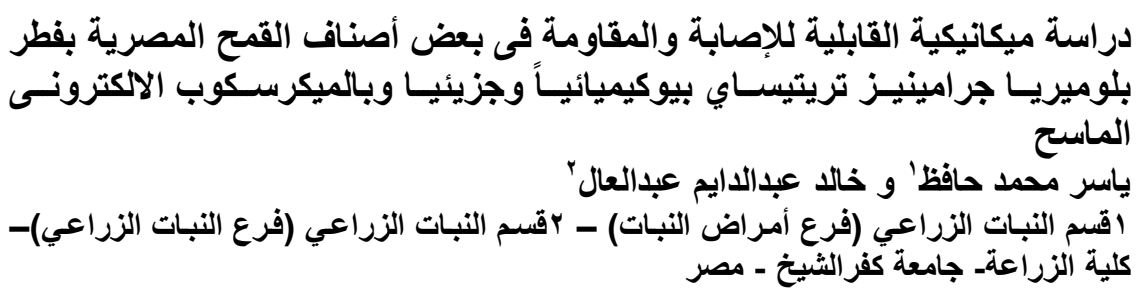

أجريت تجربتان داخل صوب قسم النبات الزر اعى بكلية الزر اعة، جامعة كفر الثيخ خلال

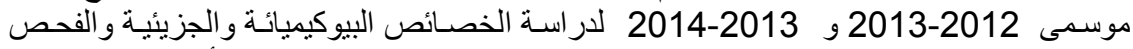

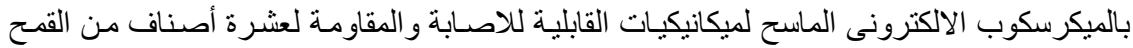

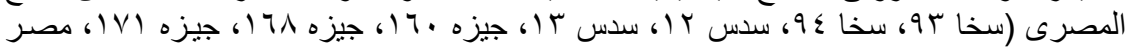

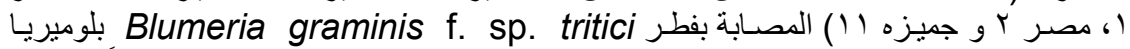

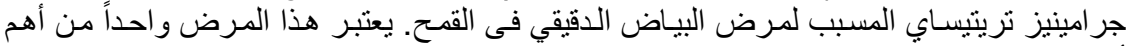

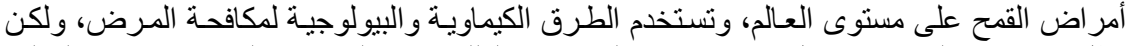
تظل الاصناف المقاومة افضل استر اتيجيات المقاومة، ولذلك يجب التبارية التعرف على ميكانيكيات القابلية

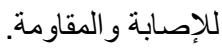

أوضحت النتائج أنه عندما تمت العدوى بـالفطر المسبب للبياض الدقيقي على أصناف أصناف قمح

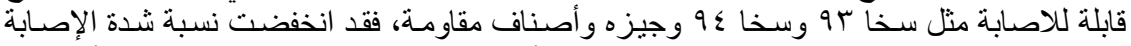

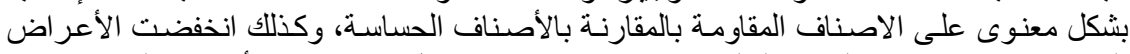

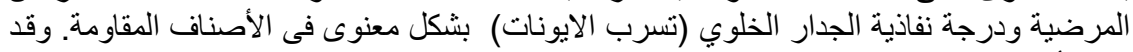

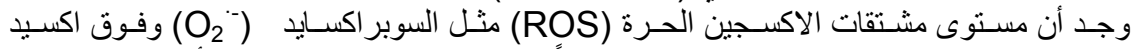

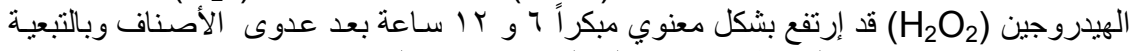

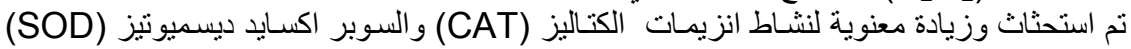

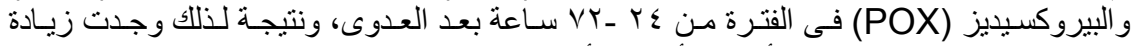

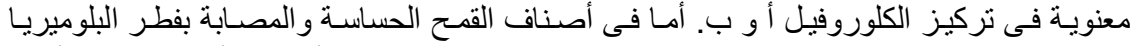

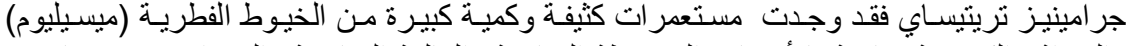

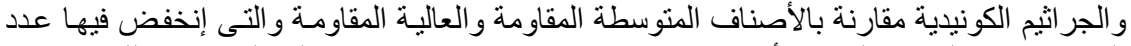

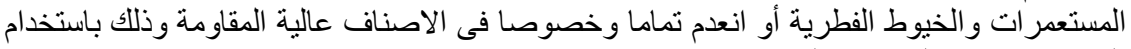
الميكروسكوب الالكترونى الماسح (SEM)

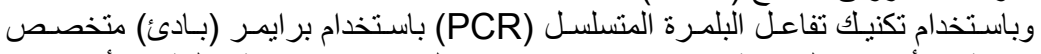
تم إثبات أن جين المقاومة (SSR)

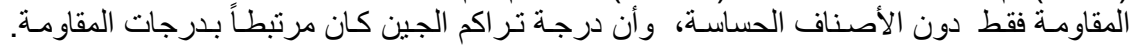

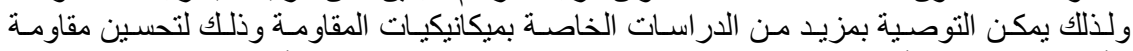
الأصناف و إستنباط أصناف جديدة بها جينات المقاومة المرتبطة بمشتقات الأكسجين الحرة (ROS). 